$\begin{array}{llllllll}\text { A } & \text { R } & \text { T } & \text { Y } & \text { K } & \text { U } & £ & \text { Y }\end{array}$

Radosław Gaziński

University of Szczecin, Institute of History

ORCID: https://orcid.org/0000-0002-6734-9309

email: radoslaw.gazinski@usz.edu.pl

\title{
Parish Registers in the Archival Fonds of the State Archives in Szczecin
}

\section{Księgi metrykalne w zasobie Archiwum Państwowego w Szczecinie}

\begin{abstract}
The article aims to show the value that Protestant parish registers kept in the State Archives in Szczecin have for demographic research. The paper will also examine the internal structure of the Pomeranian and New Marchian parish registers, showing the changes that took place in the records over a period of more than 350 years (from the end of the 16th century to the mid-20th century). The material is also intended to encourage academics to use the sources in their research work.
\end{abstract}

\section{Keywords}

Protestant parish registers, State Archives in Szczecin, Pomerania, the New March, historical demography

\begin{abstract}
Abstrakt
W artykule wskazano na wartość, jaką dla badań demograficznych przedstawiają ewangelickie księgi metrykalne przechowywane w Archiwum Państwowym w Szczecinie. Zaprezentowano również strukturę wewnętrzną pomorskich i nowomarchijskich ksiąg metrykalnych z ukazaniem zmian zachodzących w zawartych w nich zapisach na przestrzeni ponad 350 lat (od końca XVI do połowy XX w.). Materiał ma również zachęcić potencjalnych naukowców do wykorzystywania opisanych źródeł w pracy badawczej.
\end{abstract}

\section{Słowa kluczowe}

ewangelickie księgi metrykalne, Archiwum Państwowe w Szczecinie, Pomorze, Nowa Marchia, demografia historyczna 
The main goal of the article is to familiarize researchers with the content and to demonstrate the scientific value of Pomeranian and New Marchian parish registers currently stored in the State Archives in Szczecin for historical demographic research. In addition, analysis of the books' contents will allow the author to show the changes (differences, similarities) that took place from the end of the 16th century to the mid-20th century in the records (baptisms/births, weddings, and funerals/deaths) contained in these books. The work is also intended to encourage academics to undertake research efforts in this area of Pomerania and the New March which thus far has been unexplored.

Parish registers in Pomerania and the neighboring counties (the New March/ Brandenburg) first appeared in the middle of the 16th century with the strengthening of Lutheranism in these lands. ${ }^{1}$ In the duchies ruled by the Griffin dynasty (the Duchy of Wolgast and Szczecin), registration of vital events was recommended to new Lutheran pastors by the local parliament in Trzebiatów (1534), where the dukes decided to introduce Protestantism in Pomerania. ${ }^{2}$ However, it should be emphasized that although the oldest known Pomeranian parish register (the marriage register from Wołogoszcz/Wolgast) was established in $1538,{ }^{3}$ the process of creating subsequent parish registers in Pomerania was very slow and met with many difficulties. No wonder then that in 1568 Dukes Barnim IX and Philip I, as guardians of the Pomeranian church, categorically ordered pastors to keep at least marriage registers. This ordinance had a rather limited effect, since in the second half of the 1590s, marriage registers were kept in only a dozen or so parishes ${ }^{4}$ out of about 400 which existed in Pomerania at that time. In March 1616, during the national sejmik, and then in December 1617, the Duke of Szczecin, Philip II, issued ordinances requiring the pastors under his authority to keep three classes of parish registers, i.e., of baptisms, marriages, and funerals. ${ }^{5}$ These orders also

${ }^{1}$ On the causes and course of the Lutheran reform and the organization of the Lutheran Church in Brandenburg, see Bogdan Wachowiak and Andrzej Kamieński, Dzieje Brandenburgii-Prus na progu czasów nowożytnych (1500-1701) (Poznań: Wydawnictwo Poznańskie, 2001), 168-193; the publication also includes a list of basic literature. On the Lutheran revolution in Pomerania, see Bogdan Wachowiak, "Reformacja na Pomorzu Zachodnim i w Nowej Marchii," in: Historia Pomorza, vol. 2: Do roku 1815, ed. Gerard Labuda, part 1: (1464/66-1648/57), ed. Marian Biskup et al. (Poznań: Wydawnictwo Poznańskie, 1976), 802-825, where also basic literature on the subject can be found.

${ }^{2}$ Wachowiak, "Reformacja," 814-816; compare also: Radosław Pawlik, Kapituła katedralna w Kamieniu Pomorskim na przełomie epok (1498-1549) (Warszawa-Szczecin: Archiwum Główne Akt Dawnych, Archiwum Państwowe w Szczecinie, Stowarzyszenie Archiwistów Polskich, 2019), 203-208.

${ }^{3}$ Martin Wehrmann, "Die Kirchenbücher in Pommern," Baltische Studien AF 42 (1892): 204.

${ }^{4}$ Martin Wehrmann confirmed that books were kept in 18 parishes: Wehrmann, "Die Kirchenbücher," 204-205.

${ }^{5}$ Keeping three classes of books was ordered in 1616 by the local parliament of the Duchy of Szczecin: Wehrmann, "Die Kirchenbücher," 206-209. 
had a rather limited effect. Actually, before the Thirty Years' War reached Pomerania (1627), all three types of vital event registers were kept mainly in urban and rural parishes located in the immediate vicinity of towns that were considered large on the local Pomeranian scale (e.g., around Szczecin, Stralsund, Greifswald, Kołobrzeg, Stargard or Słupsk).

The Thirty Years' War, which caused great destruction in Pomerania and Brandenburg, ${ }^{6}$ and a significant loss of population in both duchies, also led to the situation where the post of pastor remained vacant in many parishes. As a result, vital records obviously ceased to be kept in many Pomeranian and New Marchian parishes. It is known that a stabilization began in the 1640s. Martin Wehrmann calculated that in the years 1640-1649, parish registers were kept in 44 Pomeranian parishes, ${ }^{7}$ and in the years 1650-1659, in the Brandenburg part of Pomerania, they were kept in 60 parishes. However, it was only at the end of the 17th century that 360 Pomeranian parishes out of the 450 existing kept the three classes of parish registers ordered by the authorities. In the 18th century, the Prussian kings gradually forced all Pomeranian and Brandenburg parishes to regularly record vital events in their area, and the records were given a strictly defined content. Moreover, it was forbidden to record these demographic facts on separate pieces of paper, and they were ordered to be entered directly into the parish registers. Reluctant pastors who did not keep their books systematically or kept them carelessly (illegibly) were fined (ordinances from 1760 and 1764). ${ }^{8}$ A Prussian national law issued in 1794 introduced comprehensive provisions relating to the keeping of parish registers by pastors. The pastor was required to enter notes on baptism, marriage or death into the appropriate register immediately after the event, according to a strictly defined internal structure. He was to do it carefully and legibly. The pastor was required to make entries in the original books. On the other hand, the sacristan could, on the basis of the pastor's record, make a note in duplicate parish registers. The pastor was also required, at the end of each year, to send information on vital events in his parish to the nearest court of lowest instance. Pomeranian pastors were ordered to comply with the regulations of the

\footnotetext{
${ }^{6}$ On the Thirty Years' War in Brandenburg: Wachowiak, Kamieński, Dzieje Brandenburgii, 334-355; in Pomerania: Bogdan Wachowiak, "Upadek państwa zachodniopomorskiego," in: $\mathrm{Hi}$ storia, ed. Biskup et al., 994-1003.

${ }^{7}$ Wehrmann, "Die Kirchenbücher," 210.

${ }^{8}$ The church was intended to become an efficient part of the Prussian state: Zygmunt Szultka, "Stosunki wyznaniowe i kościelne w Prusach w XVIII w.," in: Prusy w okresie monarchii absolutnej (1701-1806), ed. Bogdan Wachowiak (Poznań: Wydawnictwo Poznańskie, 2010), 745-764; compare also: Bogdan Wachowiak, "Stosunki wyznaniowe i kościelne w XVIII i początkach XIX wieku," in: Historia Pomorza, ed. Gerard Labuda, vol. 2: Do 1815, part 3: Pomorze Zachodnie w latach 1648-1815, ed. Zygmunt Szultka et al. (Poznań: Wydawnictwo Poznańskie, 2003), 842$848,856-860$.
} 
Landrecht in this matter by a separate order of the Pomeranian Consistory (1796), and Brandenburg pastors by the Brandenburg Consistory (1795). The obligation to keep record books by parishes (throughout Prussia) was suspended in 1874, when civil registry offices were established in the Kingdom of Prussia. This was when the state took over the supervision over vital events. Parishes then gave up keeping duplicate books, although they continued to keep original parish registers until 1945.

Pomeranian parish registers were relatively infrequently used in historical research. Martin Wehrmann was the first to become interested in them as a source. ${ }^{9}$ It was he who made a list, highly valuable today, of all the parish registers in existence in Pomeranian parishes at the time (1892). Wehrmann's catalog was the result of a growing interest in genealogical issues at the end of the 19th century. In the 1930s, in connection with racial research in the Third Reich, both the Pomeranian and New Marchian parish registers were used by the Nazi authorities to analyze the racial purity of German citizens.

The Second World War led to the dispersal of and significant losses among the Pomeranian and New Marchian parish registers kept at that time in parishes. Hence, today we can find Pomeranian and New Marchian parish registers in, e.g., the Protestant Central Archives in Berlin (Evangelisches Zentralarchiv in Berlin),${ }^{10}$ the Church Archives in Greifswald (Landeskirchliches Archiv in Greifswald) ${ }_{1}^{11}$ and in the State Archive in Greifswald (Landesarchiv Greifswald). ${ }^{12}$ On the Polish side of the border, some Pomeranian and New Marchian parish registers are kept in the State Archives in Koszalin and in the State Archives in Gorzów Wielkopolski, ${ }^{13}$ while some constitute a separate collection in the State Archives in Szczecin. ${ }^{14}$

\footnotetext{
${ }^{9}$ Wehrmann, "Die Kirchenbücher," 201-214 introduction, 215-280, list of books.

${ }^{10}$ Christa Stache, ed., Verzeichnis der Kirchenbücher im Evangelischen Zentralarchiv in Berlin (Berlin: Evangelisches Zentralarchiv in Berlin, 1992), 247-270, 293-296.

${ }^{11}$ Inventory of parish registers in the Church Archives, Greifswald: Carlies Maria Raddatz, ed. Landeskirchliches Archiv Greifswald (Greifswald: Landesarchiv Greifswald, 1995), 8-19.

${ }^{12}$ Uwe Rodig, ed., Verzeichnis der pommerschen Kirchenbücher im Vorpommerschen Landesarchiv Greifswald (Rostock-Bremen: Edition Temmen, 1996), 20-335.

${ }^{13}$ Dariusz A. Rymar, ed., Archiwum Państwowe w Szczecinie Oddziat w Gorzowie Wielkopolskim. Przewodnik po zasobie archiwalnym (Warszawa: Naczelna Dyrekcja Archiwów Państwowych - Wydział Wydawnictw, 2002), 86-88. It is worth mentioning the guide to parish registers and the books of registry offices in the New March: Georg Grüneberg, ed., Kirchenbücher, Kirchenbuch-Duplikate und Standesamtsregister der ehemals brandenburgischen Kreise Königsberg, Soldin, Landsberg, Arnswalde, Friedeberg, Ost- und Weststernberg, Crossen, ZüllichauSchwiebus, Guben und Sorau, Schwerin, Meseritz, Bomst. Bestandverzeichnis (Lenzen: Verlag G. Grüneberg, 1998), 15-266.

${ }^{14}$ Compare also the microfilms of parish registers kept in Leipzig: Martina Wermes et al., eds., Bestandverzeichnis der Deutschen Zentralstelle für Genealogie Leipzig, Part 1: Die
} 
The books that currently make up the collection in Szczecin were placed in the local facility as part of a drive by the Polish archival authorities to secure post-German church records. During this undertaking, not only parish files were secured, including parish registers, but also archives of superintendencies. ${ }^{15}$ Books from Protestant Pomeranian and Brandenburg (New Marchian) parishes were combined into one collection, which in the 1960s consisted of 177 archival items. Successive inflows of archival materials, especially duplicate parish registers kept in regional courts (Amtsgerichte), led to significant changes. Ultimately, it was decided to include the duplicate parish registers in the existing collection. As a result of this decision, the collection was supplemented with duplicates and then re-ordered. In 1991, Jerzy Grzelak separated duplicate books from the collection of parish registers and included them again in the fonds of the relevant regional courts. As a result of these activities, in 1991 the newly rearranged collection of parish registers amounted to 271 archival items. In 1992, Jerzy Grzelak published a list of Szczecin's parish registers and their duplicates. ${ }^{16}$ A reclassification of the collection carried out in 2010 by Alicja Kościelna reduced the number of books to 232 archival items, which was due to the exclusion of some books from church provinces other than Pomerania and Brandenburg. ${ }^{17}$ The Szczecin collection of parish registers created after the war has not been the subject of indepth analysis so far. It has been used almost exclusively for fragmentary genealogical research conducted mainly by German citizens. ${ }^{18}$ Only the Jasienica parish marriage registers have been more thoroughly examined..$^{19}$ At this point, it is worth adding that the revival of genealogical research in Poland has resulted in an increase in the literature on parish registers. ${ }^{20}$ These works were usually

Kirchenbuchunterlagen der östlichen Provinzen Posen, Ost- und Westpreußen, Pommern und Schlesien (Neustadt/Aisch: Verlag AG Degener \& Co, 1991), 79-84.

${ }^{15}$ Jerzy Grzelak, "Spis ksiąg metrykalnych i ich duplikatów w zasobie Archiwum Państwowego w Szczecinie," Szczeciński Informator Archiwalny 7 (1992): 54-56.

${ }^{16}$ Grzelak, "Spis," 53-141, compare also: Herbert Spruth, "Pommersche Kirchenbücher und Standesamtsregister 1968," Baltische Studien 54 [according to the new numbering system] (1968): 115-116, 121-122; and Radosław Gaziński, Paweł Gut, Maciej Szukała, eds., Archiwum Państwowe w Szczecinie. Przewodnik po zasobie archiwalnym. Akta do 1945 roku (Warszawa-Szczecin: Naczelna Dyrekcja Archiwów Państwowych - Wydział Wydawnictw, 2002), 392-406.

${ }^{17}$ Alicja Kościelna, Inwentarz. Zbiór ewangelickich ksiąg metrykalnych z Pomorza i Nowej Marchii 1581 -1947 (Szczecin: Archiwum Państwowe w Szczecinie, 2011), 2-75.

${ }^{18}$ Grzelak, "Spis," 53.

${ }^{19}$ Radosław Gaziński et al., "Śluby w ewangelickiej parafii Jasienica pod Szczecinem w latach 1778-1880," Przeszłość Demograficzna Polski 28 (2007): 27-111.

${ }^{20}$ Czesława Hruszka, "Księgi metrykalne i akta stanu cywilnego w zasobie Archiwum Państwowego w Poznaniu," Archeion 55 (1970): 59-78. Dariusz A. Rymar, Stanisława Janicka, Teresa Kuciak, "Spis ksiąg metrykalnych i ich duplikatów w zasobie Oddziału AP w Gorzowie Wielkopolskim," Szczeciński Informator Archiwalny 8 (1993): 69-135; Zofia Szulc, "Akta metrykalne w zbiorach Archiwum Państwowego w Rzeszowie," Prace Historyczno-Archiwalne 4 (1996): 


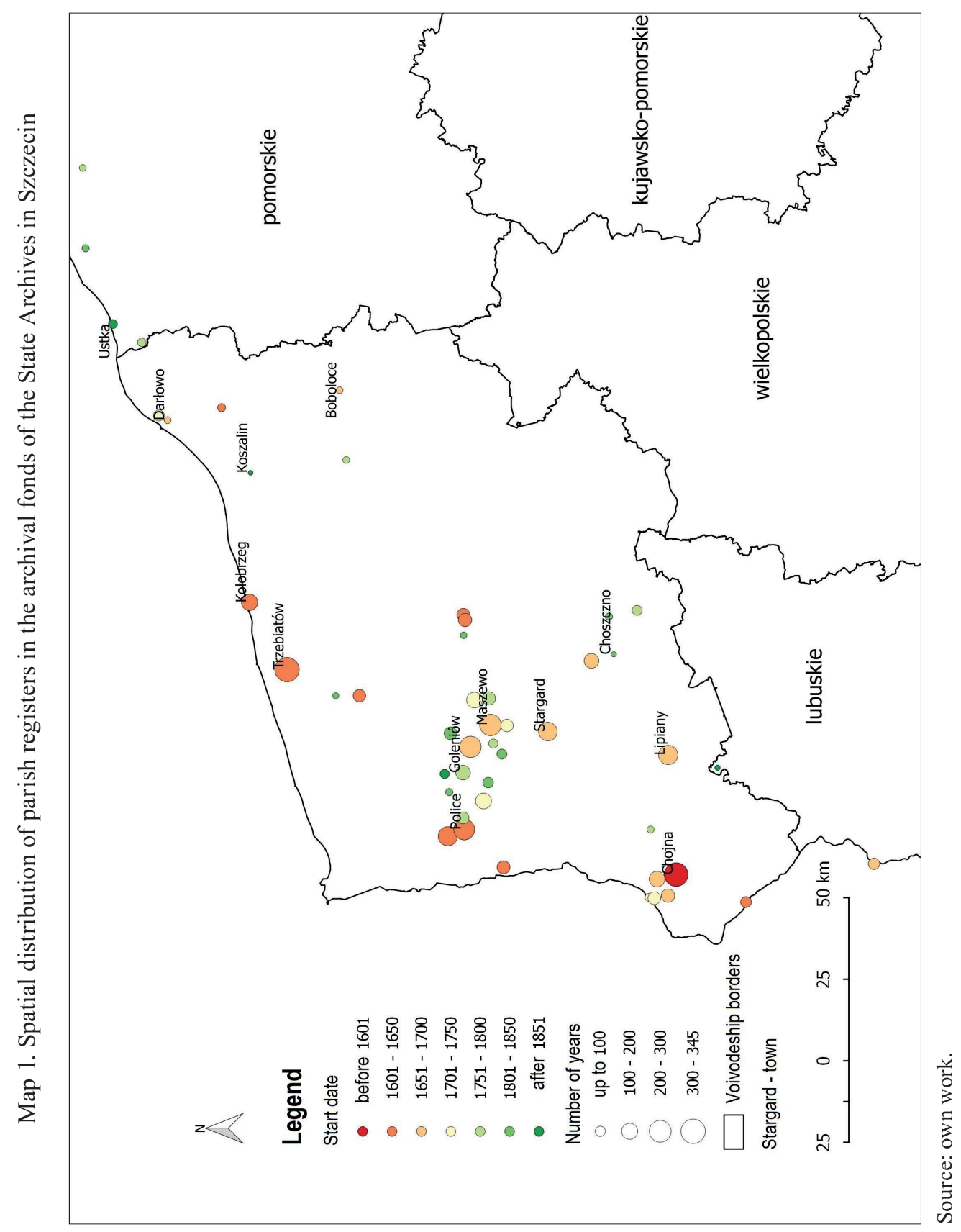


created in the archival environment and their culmination was a guidebook by Anna Laszuk ${ }^{21}$ and the electronic database Pradziad. Research carried out by archivists has found a wider response among historians and genealogists, which has resulted in the accumulation of new valuable publications. ${ }^{22}$

Parish registers in the State Archives in Szczecin today constitute a separate collection called the Collection of Protestant Parish registers from Pomerania and the New March. ${ }^{23}$ This means, first of all, that numerous small fonds in Szczecin were combined into one whole, creating a collection of partial fonds, including partial fonds from 61 Protestant parishes. Secondly, these parishes functioned in several neighboring provinces. Of course, the vast majority of them (42 parishes) were located in historical Pomerania. The second largest group of archival materials (parish registers) relates to parishes located in the area of the former New March (13 parishes), which was part of Brandenburg. The collection also includes partial fonds of parish registers (3 parishes) from former West Prussia (Royal Prussia) and (3 parishes) from East Prussia (the Duchy of Prussia). In total, the

244-254; Anna Krochmal, Michał Proksa, Akta metrykalne w zasobie Archiwum Państwowego w Przemyślu (Przemyśl: Archiwum Państwowe w Przemyślu, 1998), 185.

${ }^{21}$ Anna Laszuk, comp., Księgi metrykalne i stanu cywilnego $w$ archiwach państwowych. Przewodnik (Warszawa: Naczelna Dyrekcja Archiwów Państwowych, 2003), 475; the electronic database Pradziad is an extension of the guide: www.archiwa.gov.pl/pl/768-księgi-metrykalne-istanu-cywilnego-pradziad.

${ }^{22}$ The following publications should be mentioned: Józef Mandziuk, "Księgi metrykalne województwa jeleniogórskiego w Archiwum Archidiecezjalnym we Wrocławiu," Przeszłość Demograficzna Polski 16 (1985): 197-203; Małgorzata Kośka, Dorota Lewandowska, "Księgi metrykalne różnych wyznań z terenów tzw. zabużańskich przechowywane w AGAD," Przeszłość Demograficzna Polski 20 (1997): 129-144; Wiesława Kwiatkowska, Kancelaria Ewangelickiego Kościoła Unickiego w Prusach Zachodnich w latach 1817-1924 i pozostałe po niej akta (Torun: Wydawnictwo Naukowe Uniwersytetu Mikołaja Kopernika, 2006), where on pp. 98-107 the forms of the parish registers are described, and recently: Wojciech Ziobro, "Księgi metrykalne parafii rzymskokatolickiej w Strzyżewie z lat 1784-1918 - stan zachowania i możliwość odtworzenia ruchu naturalnego ludności," Przeszłość Demograficzna Polski 39 (2017): 97-115; Wojciech Ziobro, Radosław Waśko, "Bazy danych w opracowaniu galicyjskich ksiąg metrykalnych," Galicja. Studia i Materiały 4 (2018): 289-304 and Sławomir Kościelak, "Katolicka społeczność Gdańska w świetle ksiąg metrykalnych z II połowy XVIII wieku. Nowe spojrzenie na przemiany demograficzne w wielowyznaniowym protestanckim ośrodku," Przeszłość Demograficzna Polski 40 (2018): 83-103.

${ }^{23}$ It is worth adding at this point that today, in state archives, collections of partial fonds are no longer being built, especially in one collection of record creators operating in various administrative units of a higher level (in this case, in various church provinces). However, in Szczecin, during the works on the electronic version of the inventory in 2010, it was concluded that the above-mentioned collection had been functioning as a whole for over 50 years and there is no justification for dividing it into numerous, usually simple partial fonds. The arguments also referred to numerous examples of collections of parish registers that still function in the Central Archives of Historical Records. It should also be mentioned that the books from three parishes from the area of East Prussia were separated from the collection with the intention of transferring them to the State Archives in Olsztyn. 
Szczecin collection consists of 232 archival items, which amounts to 10.5 linear meters of files for the years 1581-1947. If we look at the affiliation of the these parish registers to particular church provinces, 165 archival items remained from Pomerania for the years 1600-1947, with 60 archival items from Brandenburg (the New March) for the years 1581-1943, 4 archival items from West Prussia for the years 1824-1874, and 3 archival items from East Prussia for the years 16801814. The parish registers in question contain all three classes of entries: baptisms, including baptisms of illegitimate children, marriages and marriage banns, deaths, confirmations, and finally records of people receiving holy communion (communicants). The German language dominates in these books, although there are entries in Latin, Greek, and Hebrew. These archival materials are the products of Protestant (Lutheran) parishes, and after 1817 (when the Prussian king Frederick William III united Lutherans with Calvinists), of United Protestant parishes. Of 42 Pomeranian parishes, only 1 or 2 parish registers have survived from 27 parishes. In the remaining 15 parishes, more than 2 books have survived, but only 7 parishes have more than 10 parish registers. Pomeranian record holders include the parishes in Goleniów (17 archival items), the parish of the Holy Spirit in Stargard (16 archival items), and in Maszewo (14 archival items). In the case of Brandenburg province (the New March), in the surviving 13 parishes, only 7 have more than 1 book. The record holders, with more than 10 books, include the parishes in Chojna and Lipiany, both with 17 archival items. If we look at the chronological distribution of entries, books containing entries from the 19th and the first half of the 20th centuries are clearly predominant. Only around a quarter of the books date back exclusively to the 17th and 18th centuries. In the case of 165 parish registers from Pomerania, only 40 contain entries exclusively from the 17th and 18th centuries. It should be added here that the 17th-century records appear only in 19 books (mainly from the second half of the 17th century), and of those dating back to the times of the duchies there are only four (the oldest from 1600 are included in the register of births at St. Mary's Church in Trzebiatów). For the New March (Brandenburg), of the 60 preserved parish registers, only 22 contain records all predating the 19th century. On the other hand, in 11 books we can find references from the 17th century, mainly from the second half. Only in Chojna two baptism and death registers have been preserved, which date back to the times before the outbreak of the Thirty Years' War (from 1581).

Thus, the oldest entries in the parish registers kept by Pomeranian parishes date back to 1600 (the first entry was dated 18 August 1600), and in those kept by parishes in the New March to 1581 (the first entry is from 14 May 1581). The oldest Pomeranian parish register preserved in the Szczecin archives is the baptism 
register from the Church of the Blessed Virgin Mary in Trzebiatów. ${ }^{24}$ The notes it contains on the demographic events for the years 1600 to 1668 are very brief. They consist of the date of baptism (day, month), sex of the child, the first name(s) and surname of the father, the name(s) of the child himself/herself, and the names and surnames of the witnesses to the baptism. Among the witnesses to the baptism (usually three or four people), men were greatly prevalent. With time (beginning in the 1620s), there were also women, most often one woman for every two or three men. At the end of each year, the pastor who kept the book summarized the number of babies baptized. It must be added that the structure of the record did not change until the end of the book. The oldest book from the New March, in turn, includes entries for the years 1581-1600 concerning baptisms and deaths in the parish of the Church of the Blessed Virgin Mary in Chojna. ${ }^{25}$ Notes on demographic events are kept here in two columns. Information on baptisms was written on the left side, while the right side listed deaths/funerals. The records were very simple and brief. In the case of a baptism, the date of the child's baptism was recorded (day, month, year was given at the top of the page), along with the name(s) and surname of the child's father, the mother's first name(s) and maiden name, sex and first name(s) of the child, and finally the names and surnames of witnesses to the baptism (usually two or three). As in the Trzebiatów parish register, there were far more male witnesses. In some records in the $1590 \mathrm{~s}$, the name and sex of the child appear immediately after the date of baptism, and only then were the father's details recorded (often together with his occupation/ estate), as well as the details of the mother and of the witnesses to the baptism. Data on deaths/funerals were recorded much more briefly. In the case of adults, the records amounted to providing the date of the funeral and the name(s) and surname of the deceased, and, in the case of children, the date of the funeral, the name(s) and surname of the father, sometimes the child's sex, and his or her first name. ${ }^{26}$ At the end of each year, the pastor made a summary of how many children had been born in the parish and how many people had died. Additionally, the book contains the statistics of communicants included in a table consisting of the list of consecutive Sundays and the number of persons given Holy Communion on those Sundays by the pastor and two curates. The next parish register of the Church of the Blessed Virgin Mary in Chojna for the years 1600-1631

\footnotetext{
${ }^{24}$ Archiwum Państwowe w Szczecinie (hereafter: APSz), Zbiór Ewangelickich Ksiąg Metrykalnych z Pomorza i Nowej Marchii (hereafter: ZEKMPNM), archival reference no. 154.

${ }^{25}$ APSz, ZEKMPNM, archival reference no. 173: the oldest record in the book is dated 14 May 1581. On that day, Andreas Friske and Dorota Gores had their son David baptized in the presence of the witnesses Casper Masbach, Balthasar Widmans, Hans Fuile, and Christoph Wolk.

${ }^{26}$ The earliest death was recorded on 16 May 1581, when Joachim Beldikans' child was buried.
} 
contains an identical structure of records arranged in two columns (baptisms/funerals). ${ }^{27}$ The only minor differences are that the number of witnesses to baptisms increased to 10 in some cases (among whom the majority were still men), and in the case of funerals, the age at death of the elderly deceased was given. ${ }^{28}$ Each year, the pastor would still summarize the births and deaths and compile a table that recorded the number of communicants. Equally brief and simple entries can be found in the book of baptisms of the Church of the Blessed Virgin Mary in Kołobrzeg covering the years $1633-1676 .{ }^{29}$ They were recorded in the following order: the date of the event, the child's name(s), the father's name(s), sometimes his estate/occupation, and the names and surnames of the witnesses. In the few cases of illegitimate births, the mother's first name(s) and surname were recorded. Twin births (also very few in number) were joined with a curly bracket and followed by the name(s) and surname of the children's father. After each year, the number of babies baptized was totaled. Schematic data are also included in the marriage register from the parish of the Blessed Virgin Mary in Kołobrzeg from $1682-1703 .{ }^{30}$ The records have a standardized content which consists of the date of the wedding (day, month, year), the groom's name(s), surname, and sometimes estate/occupation, the bride's name(s) and surname, as well as (although not always) the name(s), surname, place of residence, and estate/occupation of the father of the bride. In a few cases, after the data on the father of the bride, information stating which of his daughters (younger, older) had married was added. A very interesting example of a parish register from a relatively small, town parish is the church book of Bobolice, containing baptism records from 1657-1696. The book begins with a chronicle of the most important events that took place in the years 1657-1687 in the Reich, Brandenburg, and Pomerania. ${ }^{31}$ On the other hand, the baptism entries themselves were included in a handwritten table ${ }^{32}$ with the following columns: date of baptism (day, month, year at the top of the table) (1), the child's first name(s) (2), the name(s), surname, and sometimes occupation/ estate of the father, the name(s) and maiden name of the mother (3), the names and surnames of the baptism witnesses (4). The estate/occupation of men who were witnesses were often recorded and, in the case of women, their maiden names. From 1666, the dates of birth of baptized children appeared in the first column instead of the dates of baptism, and the latter were added after the name(s) of the

\footnotetext{
${ }^{27}$ APSz, ZEKMPNM, archival reference no. 174.

${ }^{28}$ The most frequently recorded age was over 70 years, but the oldest deceased person found during the analysis of the book was 90 years old.

${ }^{29}$ APSz, ZEKMPNM, archival reference no. 40.

${ }^{30}$ Ibidem, archival reference no. 44.

${ }^{31}$ Ibidem, archival reference no. 2, the above-mentioned chronicle covers pages 3-19.

${ }^{32}$ It is the oldest handwritten table preserved in the parish registers kept in Szczecin.
} 
children in the second column. A cross was also drawn here if the child died soon after baptism. From the beginning of the 1670s, the estate/occupation of the father of the baptized child was almost always mentioned (column 3). It is worth adding that this book is supplemented by indexes of the baptized children, arranged chronologically according to the dates of baptism (baptism date, date of birth, name(s) of the child, and name(s) of his or her father). ${ }^{33}$ It ends with a chronological list of confirmed children (subsequent year, name(s), and surname of the confirmed child). ${ }^{34}$

During the 18th century, notes on demographic events were fully standardized, and from the second half of the century they were almost exclusively included in handwritten tables. Examples of books from the first half of the 18th century, from the period before the introduction of tables, include books from the Church of the Blessed Virgin Mary in Kołobrzeg: the marriage register from 1706-1758 ${ }^{35}$ the deaths register from $1708-1747 .{ }^{36}$ In the first of these books, following the cited 18th-century regulations on the methods of registering vital events, the records are standardized, chronologically arranged, and contain the following data: date of the wedding (day, month), name(s), surname, estate/occupation of the groom, and place of residence if he was not from Kołobrzeg, name(s) and surname of the bride, and the name(s), surname, and estate/occupation of the father of the bride, as well as his place of residence if he was not from Kołobrzeg. Each marriage concluded by a widower or widow was also clearly marked. In the latter case, the name, surname, and the estate of the deceased husband were given. The book also contains chronologically arranged lists of those who had been confirmed (name, surname, and age of the confirmed person). The second of the books from the Church of the Blessed Virgin Mary in Kołobrzeg, the death register for the years 1708-1747, also contains schematically arranged chronological records including the date of the funeral/death, name(s) and surname of the deceased, sometimes their place of residence, and the place of burial. For men, this is supplemented by the estate/occupation of the deceased. In the case of women, next to the date of death/funeral, their first name(s) and maiden names were given, as well as personal details of their husbands, even if they were already dead. When a child died, the father's name(s), surname, and estate/occupation were always recorded, as well as the child's sex, but much less often their first name. The age of the deceased was rarely given.

\footnotetext{
${ }^{33}$ APSz, ZEKMPNM, archival reference no. 2, 179-211, 227-248.

${ }^{34}$ Ibidem, archival reference no. 2, 249-266, 306-310.

${ }^{35}$ Ibidem, archival reference no. 45.

${ }^{36}$ Ibidem, archival reference no. 47.
} 
Books from the area of the New March that record vital events contain similarly formulaic records in the first half of the 18th century. The book from Krzymów parish can serve as an example. It is worth adding here that in the case of small parishes, regardless of their location (Pomerania or the New March), one book contained the records of all the demographic events: births, marriages, and deaths. In Krzymów ${ }^{37}$ parish in the New March, these records from 1707-1751 contained data that were uniform in terms of content. In the case of births, these were always: the child's date of birth, the father's details, the date of baptism, the sex and name of the child, and the personal details of the baptism witnesses. Only at the end of the book (1750-1751) did the details of the baby's mother begin to appear. Information on marriages consisted only of the wedding date, the personal details of the groom, and then of the bride. The death records were similar, consisting of the date of death and the name and surname of the deceased. ${ }^{38}$

The parish book of Pomeranian Jasienica, 1776-1796 already constitutes an example of a book in which all data on the vital events were included in identical handwritten tables, compiled in accordance with royal regulations. ${ }^{39}$ For births, the table contained the following information: the consecutive number of the event (1), date of the child's baptism (2), his or her name and date of birth (3), the father's personal details (4), the mother's personal details (5), the personal details of both of the child's grandfathers (6), the personal details of both of the child's grandmothers (7), the personal details of the godparents (8), and potential comments (9). A table compiled in this way was kept separately for boys and girls. In 1778, minor changes were introduced to the table described. Firstly, a separate column was added with the child's date of birth and, before the main table, information (in columns) was given recording the total number of children born and baptized, and the number of legitimate and illegitimate boys and girls. The table of deaths was more complicated. Initially, it had a transitional form between the standardized notes from the first half of the 18th century and the concise table from the second half of that century. All the deceased were divided into age groups: under 5 years of age (1), 6 to 10 years (2), 10 to 20 years (3), deceased husbands (4), deceased wives (5), deceased widowers (6), and finally, deceased widows (7). In each of the columns, a brief note on the deceased was entered. In the case of children who had died before the age of 10 (columns 1,2), the names, surnames, date of death, date of funeral, and sometimes the age at death were given. For adolescents up to the age of 20 , these were: the date of death, the date of the funeral, the name

\footnotetext{
${ }^{37}$ Ibidem, archival reference no. 146 .

${ }^{38}$ In the case of a deceased child, the personal details of the father were always given, and only sometimes the name of the child himself or herself.

${ }^{39}$ APSz, ZEKMPNM, archival reference no. 28.
} 
and surname, name and surname of the father, and age at death (column 3). In the case of adults, the following information was recorded for married men: the date of death, date of funeral, name and surname, occupation, place of residence, age at death (column 4), and for married women: date of death, date of funeral, name and maiden name, husband's name, surname, and occupation, place of residence, age at death (column 5). For widowers and widows, the same data were reported as for married men and women (columns 6 and 7 respectively). In 1777, the table was reversed, starting with married men, then married women, widowers, widows, and finally adolescents and children. It was only in 1778 that a standardized table of the deceased was introduced to the Jasienica parish register, in which the basic data included in 5 columns were: date of death (1), date of funeral (2), personal details of the deceased (3), cause of death (4), and age of the deceased (5). The general statistics of deaths during a given month were still given; later, the deceased began to be listed according to their marital status (married men, married women, widowers, widows, children) and with a division into the villages constituting Jasienica parish.

In the 19th and 20th centuries, entries in the parish registers became highly formulaic and were included almost exclusively in handwritten tables, which from the mid-1830s most frequently became printed. In the Goleniów birth register from $1806-1824,{ }^{40}$ the handwritten table contained the following data: the child's first name(s) (1), the date and time of birth (2), the date of baptism (3), the father's personal details: name(s), surname, estate/occupation (4), the mother's personal details: name(s), maiden name (5), the godparents' personal details: names and surnames, and, in the case of men, their occupations (6). Initially, the table with this structure was completed separately for boys and girls. From 1811, the table was inverted, placing the columns in the following order: the child's name(s) (1), the father's personal details (2), the mother's personal details (3), the godparents' personal details (4), the date of birth (5), and finally the date of baptism (6). In the printed table of the birth register from Jasienica for the years 1863 $1880,{ }^{41}$ the same data were arranged in a slightly different order in a printed table: the child's father's details: name(s), surname, estate/occupation (1), the mother's details: name(s), maiden name (2), the name(s) of the child (3), the date of birth: time, day, month (4), whether the child was legitimate or illegitimate (5), the date of baptism (6), the personal details of the godparents (7), comments (8). The book from Jasienica ends with alphabetical and chronological lists of born and baptized children. Identical tables (like that from Jasienica) can be found in other Pomeranian birth/baptism registers from that period. For example, the registers

\footnotetext{
${ }^{40}$ Ibidem, archival reference no. 5.

${ }^{41}$ Ibidem, archival reference no. 32.
} 
from Maszewo from $1898-1934^{42}$ can be mentioned here, as well as those from the parish of the Holy Spirit in Stargard from 1876-1892, ${ }^{43}$ from the parish in Mosty from $1856-1885,{ }^{44}$ from the parish in Lubczyna from $1869-1882,{ }^{45}$ from the parish in Bolesławice from $1845-1886,{ }^{46}$ or from the parish in Sielsk from $1846-1883 .{ }^{47}$ On the other hand, the arrangement of the columns in the tables in the birth registers kept by parishes in the New March area (administered by the Brandenburg Protestant consistory) was slightly different. It is exemplified by the birth and baptism register book from Lipiany for the years $1824-1842,{ }^{48}$ in which, after the consecutive number of the event in a given year (1), the following information was given: the child's name(s) (2), the date of birth (3), information as to whether the child was legitimate or illegitimate (4), the father's personal details (5), the mother's personal details (6), the parents' place of residence (7), the date of baptism (8), the name of the pastor performing the baptism (9), and finally, the godparents' personal details (10). Identical birth tables are also found in other registers from the New March area. Examples include books from the parish of the Church of the Blessed Virgin Mary in Chojna for the years $1898-1912,{ }^{49}$ or from the parish in Lubieniów from $1855-1877 .{ }^{50}$

In the 19th and 20th centuries, the tables recording marriages in Pomeranian parishes were also standardized. These changes are exemplified by the marriage register from the parish in Police for the years $1866-1899,{ }^{51}$ in which there is a printed table with 12 columns containing the following data: the consecutive number of the event in the year (1), the name(s), surname, estate/occupation, and place of residence of the groom (2), his age with the date of birth added (3), whether he had obtained the consent of his parents or guardians to enter into marriage or whether there was any reason for him not to enter into marriage (4), whether the groom had previously been married and how the previous relationship had ended; later, in this column the groom's marital status was recorded: bachelor, widower (5), the name(s) and surname of the bride (6), the bride's age and date of birth (7), the name(s), surname, estate/occupation, and place of residence of the bride's father (8), whether the parents or guardians had consented to the marriage

\footnotetext{
${ }^{42}$ Ibidem, archival reference no. 76.

${ }^{43}$ Ibidem, archival reference no. 141.

${ }^{44}$ Ibidem, archival reference no. 130.

${ }^{45}$ Ibidem, archival reference no. 66.

${ }^{46}$ Ibidem, archival reference no. 62.

${ }^{47}$ Ibidem, archival reference no. 226.

${ }^{48}$ Ibidem, archival reference no. 194.

${ }^{49}$ Ibidem, archival reference no. 185.

${ }^{50}$ Ibidem, archival reference no. 221.

${ }^{51}$ Ibidem, archival reference no. 101.
} 
or whether there was any other reason not to conclude the marriage (9), whether the bride had already been married and how the previous relationship had ended; later, the bride's marital status was recorded here: spinster, widow (10), the date of marriage (11), and comments (12). In the Police book in question, the last column was most often used to note the consent to the marriage of the relevant registry office. Moreover, from 1878, the fields concerning the consent of parents or guardians to marriage were not filled in $(4,9)$, and from 1896 , with the exception of widowers and widows, the fields relating to the first marriage were not completed $(5,10)$. Finally, from 1898 , the age of the groom and the bride were no longer recorded $(3,7)$, with only their birthdates given. The same table layouts were also used in other Pomeranian marriage registers. Let us mention here, for example, books from the parish of the Holy Spirit in Stargard for the years $1852-1871,{ }^{52}$ from the parish in Mosty from $1858-1885,{ }^{53}$ from the parish in Lubczyn from 1863-1882, ${ }^{54}$ from the parish in Bolesławice from $1845-1885,{ }^{55}$ from the parish in Sielsk from $1846-1883,{ }^{56}$ or from the parish of the Blessed Virgin Mary in Trzebiatów from 1935-1947. ${ }^{.7}$ The tables of marriages in the New March parishes were slightly different in terms of the shape and number of columns. For example, the marriage register from the parish of the Church of the Blessed Virgin Mary in Chojna from 1898-191258 contained the following data: the consecutive number of the event (1), the groom's personal details (2), the groom's father's personal details (3), the groom's age with his date of birth (4), the bride's personal details (5), the bride's father's personal details (6), the age of the bride with her date of birth (7), the date of marriage (8), ${ }^{59}$ the personal details of the pastor officiating at the wedding (9). A similar layout of information with additional data regarding the parents' or guardians' consent to the marriage and the marital status of the couple are contained in the marriage registers from the Lubieniów parish from $1855-1877 .{ }^{60}$

In the period under discussion, the tables recording deaths in individual Pomeranian parishes were also standardized. An example of such a practice can be found in the death register from the parish of the Holy Spirit in Stargard for the

${ }^{52}$ Ibidem, archival reference no. 144.

${ }^{53}$ Ibidem, archival reference no. 130.

${ }^{54}$ Ibidem, archival reference no. 66.

${ }^{55}$ Ibidem, archival reference no. 62.

${ }^{56}$ Ibidem, archival reference no. 226.

${ }^{57}$ Ibidem, archival reference no. 228.

${ }^{58}$ Ibidem, archival reference no. 185.

${ }^{59}$ After the establishment of civil registry offices, the date of marriage in the marriage registers kept in the New March parishes was split into two: the date of the registry office wedding and the date of the church wedding.

${ }^{60}$ APSz, ZEKMPNM, archival reference no. 221. 
years $1866-1894^{61}$ containing a printed table with the following data: the consecutive number of the event in a given year (1), the name(s), surname, and occupation/ estate of the deceased; in the case of women the name(s), maiden name of the deceased woman and the name(s), surname, and the estate/occupation of her husband; in the case of minors, the name(s), surname, and estate/occupation of the father were added (2), the age of the deceased counted in years, months, and days; sometimes the date of birth of the deceased was added here (3), the day, month, and time of death, sometimes the place of death was added here (4), cause of death (5), day and month of burial (6), relatives left by the deceased (7), comments (8). The book in question ended with an alphabetical and chronological index of the deceased. Of course, the same layout of tables was used in other Pomeranian death register books. This is exemplified by death registers from the parish in Police for the years $1866-1878,{ }^{62}$ from the parish in Mosty from $1856-1885,{ }^{63}$ from the parish in Lubczyn from $1868-1882,{ }^{64}$ from the parish in Bolesławice from $1845-1886,{ }^{65}$ from the parish in Sielsk from $1846-1883,{ }^{66}$ or from the parish in Trzebiatów from 1943-1945. ${ }^{67}$ The layout of the tables was slightly different in the death registers kept in the parishes in the New March. An example in this case is the death register of the parish in Lipiany for the years $1824-1842,{ }^{68}$ whose table contains the following information: the consecutive number of the event in the year (1), the name(s) and surname of the deceased; in the case of deceased women, the husband's personal details were added, and in the case of deceased children, their father's personal details (2), the deceased's estate/occupation (3), age in years, months, and days (4), relatives left by the deceased (5), the day, month, and time of death (6), the cause of death (7), the pastor who celebrated the funeral (8), the day and month of the funeral (9), the place of burial (10). It should be emphasized here that the tables of deaths in the parishes of the New March were also standardized, which resulted from the orders of the Brandenburg Protestant consistory. The same 10-column tables can be found, among others, in the death registers from the parish of the Blessed Virgin Mary in Chojna from 1898-1912 ${ }^{69}$ or from the parish in Lubieniów from $1855-1877 .^{70}$

\footnotetext{
${ }^{61}$ Ibidem, archival reference no. 150.

${ }^{62}$ Ibidem, archival reference no. 102.

${ }^{63}$ Ibidem, archival reference no. 130.

${ }^{64}$ Ibidem, archival reference no. 66.

${ }^{65}$ Ibidem, archival reference no. 62.

${ }^{66}$ Ibidem, archival reference no. 226.

${ }^{67}$ Ibidem, archival reference no. 229.

${ }^{68}$ Ibidem, archival reference no. 199.

${ }^{69}$ Ibidem, archival reference no. 185.

${ }^{70}$ Ibidem, archival reference no. 221. It is worth adding here that the older books from the Lubieniów parish for the years 1829-1854 contain standardized chronological notes made by the
} 
Parish registers from the Szczecin collection are a valuable source for demographic research on the population of Pomerania and the New March from the end of the 16th century to the 1940s. The basic weakness of the collection in question, however, is its very poor condition. It only enables full demographic research to be carried out in the case of a few selected Pomeranian or New Marchian towns with the most complete state of preservation of their parish registers. More extensive research on the societies of both provinces, i.e., Pomerania and the New March, require deeper source research both in the Polish (mainly Koszalin and Gorzów Wielkopolski) and German (mainly Greifswald and Berlin) archives. Only complete, long-term, and arduous source research and the creation of an appropriate database for recording individual demographic events registered in parish registers can lead to a comprehensive assessment of demographic processes that took place in Pomeranian and New Marchian societies over the course of the 17th, 18th, 19th, and first half of the 20th centuries.

\section{Bibliography}

\section{Primary Sources}

Archiwum Państwowe w Szczecinie

Zbiór Ewangelickich Ksiąg Metrykalnych z Pomorza i Nowej Marchii, archival reference numbers $2,5,28,32,40,44,45,47,62,66,76,101,102,130,141,144,146$, $150,154,173,174,185,194,199,220,221,226,228,229$.

\section{Electronic Database}

Pradziad. www.archiwa.gov.pl/p1/768-księgi-metrykalne-i-stanu-cywilnego-pradziad.

\section{References}

Gaziński, Radosław, Paweł Gut, Maciej Szukała, eds. Archiwum Państwowe w Szczecinie. Przewodnik po zasobie archiwalnym. Akta do 1945 roku. Warszawa-Szczecin: Naczelna Dyrekcja Archiwów Państwowych - Wydział Wydawnictw, 2002.

Gaziński, Radosław, Agnieszka Gut, Paweł Gut, Dariusz Szudra, Maciej Szukała. "Śluby w ewangelickiej parafii Jasienica pod Szczecinem w latach 1778-1880.” Przesztość Demograficzna Polski 28 (2007): 27-111.

Grüneberg, Georg, ed. Kirchenbücher, Kirchenbuch-Duplikate und Standesamtsregister der ehemals brandenburgischen Kreise Königsberg, Soldin, Landsberg, Arnswalde, Friedeberg, Ost- und Weststernberg, Crossen, Züllichau-Schwiebus, Guben und Sorau, Schwerin, Meseritz, Bomst. Bestandverzeichnis. Lenzen: Verlag G. Grüneberg, 1998.

pastor, not yet included in a table. It also proves that pastors approached the orders of their authorities in various ways: APSz, ZEKMPNM, archival reference no. 220. 
Grzelak, Jerzy. "Spis ksiąg metrykalnych i ich duplikatów w zasobie Archiwum Państwowego w Szczecinie.” Szczeciński Informator Archiwalny 7 (1992): 53-141.

Hruszka, Czesława. "Księgi metrykalne i akta stanu cywilnego w zasobie Archiwum Państwowego w Poznaniu.” Archeion 55 (1970): 59-78.

Kościelna, Alicja. Inwentarz. Zbiór ewangelickich ksiag metrykalnych z Pomorza i Nowej Marchii 1581-1947. Szczecin: Archiwum Państwowe w Szczecinie, 2011.

Kościelak, Sławomir. “Katolicka społeczność Gdańska w świetle ksiąg metrykalnych z II połowy XVIII wieku, Nowe spojrzenie na przemiany demograficzne w wielowyznaniowym protestanckim ośrodku.” Przeszłość Demograficzna Polski 40 (2018): 83-103.

Kośka, Małgorzata, Dorota Lewandowska. “Księgi metrykalne różnych wyznań z terenów tzw. zabużańskich przechowywane w AGAD." Przeszłość Demograficzna Polski 20 (1997): 129-144.

Krochmal, Anna, Michał Proksa. Akta metrykalne w zasobie Archiwum Państwowego w Przemyślu. Przemyśl: Archiwum Państwowe w Przemyślu, 1998.

Kwiatkowska, Wiesława. Kancelaria Ewangelickiego Kościoła Unickiego w Prusach Zachodnich w latach 1817-1924 i pozostałe po niej akta. Toruń: Wydawnictwo Naukowe Uniwersytetu Mikołaja Kopernika, 2006.

Laszuk, Anna, ed. Księgi metrykalne $i$ stanu cywilnego $w$ archiwach państwowych. Przewodnik. Warszawa: Naczelna Dyrekcja Archiwów Państwowych, 2003.

Mandziuk, Józef. "Księgi metrykalne województwa jeleniogórskiego w Archiwum Archidiecezjalnym we Wrocławiu.” Przeszłość Demograficzna Polski 16 (1985): 197_ 203.

Pawlik, Radosław. Kapituła katedralna w Kamieniu Pomorskim na przełomie epok (1498-1549). Warszawa-Szczecin: Archiwum Główne Akt Dawnych, Archiwum Państwowe w Szczecinie, Stowarzyszenie Archiwistów Polskich, 2019.

Raddatz, Carlies Maria, ed. Landeskirchliches Archiv Greifswald. Greifswald: Landesarchiv Greifswald, 1995.

Rodig, Uwe, ed. Verzeichnis der pommerschen Kirchenbücher im Vorpommerschen Landesarchiv Greifswald. Rostock-Bremen: Edition Temmen, 1996.

Rymar, Dariusz A., ed. Archiwum Państwowe w Szczecinie Oddział w Gorzowie Wielkopolskim. Przewodnik po zasobie archiwalnym. Warszawa: Naczelna Dyrekcja Archiwów Państwowych - Wydział Wydawnictw, 2002.

Rymar, Dariusz A., Stanisława Janicka, Teresa Kuciak. "Spis ksiąg metrykalnych i ich duplikatów w zasobie Oddziału AP w Gorzowie Wielkopolskim." Szczeciński Informator Archiwalny 8 (1993): 69-135.

Stache, Christa, ed. Verzeichnis der Kirchenbücher im Evangelischen Zentralarchiv in Berlin. Berlin: Evangelisches Zentralarchiv in Berlin, 1992.

Spruth, Herbert. "Pommersche Kirchenbücher und Standesamtsregister 1968." Baltische Studien 54 [according to the new numbering system] (1968): 115-122.

Szulc, Zofia. "Akta metrykalne w zbiorach Archiwum Państwowego w Rzeszowie.” Prace Historyczno-Archiwalne 4 (1996): 244-254 
Szultka, Zygmunt. "Stosunki wyznaniowe i kościelne w XVIII i początkach XIX wieku.” In: Historia Pomorza, ed. Gerard Labuda. Vol. 2: Do 1815. Part 3: Pomorze Zachodnie w latach 1648-1815, eds. Zygmunt Szultka, Henryk Lesiński, Dariusz Łukasiewicz, Alfred Wielopolski, 842-874. Poznań: Wydawnictwo Poznańskie, 2003.

Szultka, Zygmunt. "Stosunki wyznaniowe i kościelne w Prusach w XVIII w.” In: Prusy w okresie monarchii absolutnej (1701-1806), ed. Bogdan Wachowiak, 745-764. Poznań: Wydawnictwo Poznańskie, 2010.

Wachowiak, Bogdan, Andrzej Kamieński. Dzieje Brandenburgii-Prus na progu czasów nowożytnych (1500-1701). Poznań: Wydawnictwo Poznańskie, 2001.

Wachowiak, Bogdan. "Reformacja na Pomorzu Zachodnim i w Nowej Marchii." In: $\mathrm{Hi}$ storia Pomorza. Vol. 2: Do roku 1815, ed. Gerard Labuda. Part 1: (1464/66-1648/57), eds. Marian Biskup, Maria Bogucka, Antonii Mączak, Bogdan Wachowiak, 802825. Poznań: Wydawnictwo Poznańskie, 1976.

Wachowiak, Bogdan. “Upadek państwa zachodniopomorskiego.” In: Historia Pomorza. Vol. 2: Do roku 1815, ed. Gerard Labuda. Part 1: (1464/66-1648/57), eds. Marian Biskup, Maria Bogucka, Antonii Mączak, Bogdan Wachowiak, 994-1003. Poznań: Wydawnictwo Poznańskie, 1976.

Wehrmann, Martin. “Die Kirchenbücher in Pommern.” Baltische Studien 42 [according to the old numbering system] (1892): 201-280.

Wermes, Martina, Renate Jude, Marion Bähr, Hans Jürgen Voigt, eds. Bestandverzeichnis der Deutschen Zentralstelle für Genealogie Leipzig. Part 1: Die Kirchenbuchunterlagen der östlichen Provinzen Posen, Ost- und Westpreußen, Pommern und Schlesien. Neustadt/Aisch: Verlag AG Degener \& Co, 1991.

Ziobro, Wojciech. "Księgi metrykalne parafii rzymskokatolickiej w Strzyżewie z lat 1784-1918 - stan zachowania i możliwość odtworzenia ruchu naturalnego ludności." Przeszłość Demograficzna Polski 39 (2017): 97-115.

Ziobro, Wojciech, Radosław Waśko. “'Bazy danych w opracowaniu galicyjskich ksiąg metrykalnych.” Galicja. Studia i Materiaty 4 (2018): 289-304.

\section{Parish registers from the archival fonds of the State Archives in Szczecin}

\section{Summary}

The article is devoted to the Pomeranian and New Marchian parish registers currently stored in the State Archives in Szczecin. At the beginning of the paper, the stages of establishing and then keeping registers recording vital events, in particular Pomeranian and New Marchian parishes, were presented. These times, which lasted over 350 years in total, were divided into three basic periods: from the 1530 s to the end of the era of the duchies, from the second half of the 17th century to the end of the 18th century (Brandenburg-Prussian period), and from the beginning of the 19th century to the mid-20th century. The subsequent part of the article addresses the problem of the very limited use 
of Pomeranian and New Marchian parish registers in the research work of both German and Polish historians. This applies equally to the pre-war and post-war periods. It should also be emphasized that the final shape of the collection of parish registers kept today in Szczecin was greatly influenced by World War II. It was what led to large losses and the dispersion of this type of sources, which are currently stored in German (Greifswald, Berlin) and Polish (Gorzów Wielkopolski, Koszalin, Szczecin) archives. Subsequently, the paper describes the archival features of the Szczecin collection of Evangelical parish registers, consisting of 232 archival items, which amounts to 10.5 linear meters of files created in the years 1581-1947. However, the essential part of this article discusses the content of all classes of books included in the Szczecin collection (births, marriages, deaths). At the beginning, the records from the oldest books from the beginning of the 16th and 17th centuries were characterized, and then sample books from the 18th century were described in detail, both those from the period before introducing tables (the first half of the century) and those from the times when all the data were placed by pastors in specially compiled tables (the second half of the century). Finally, the entries included in the tables in all classes of books from the 19th and the first half of the 20th century were analyzed. The result of this work was the identification of similarities and differences in the records contained in various classes of parish registers kept over the course of over 350 years. The differences between the tables completed in Pomeranian and New Marchian parishes were also indicated. Finally, the cognitive value of Pomeranian and New Marchian parish registers was recognized and conclusions were formulated for those who might want to conduct research in the field of historical demography based on the above-described parish registers.

\section{Księgi metrykalne w zasobie Archiwum Państwowego w Szczecinie}

\section{Streszczenie}

Artykuł został poświęcony pomorskim i nowomarchijskim księgom metrykalnym przechowywanym obecnie w Archiwum Państwowym w Szczecinie. Na początku pracy syntetycznie omówiono etapy zakładania, a następnie powadzenie ksiąg rejestrujących ruch naturalny ludności w poszczególnych parafiach pomorskich i nowomarchijskich. Czasy te, trwające łącznie ponad 350 lat, zostały podzielone na trzy zasadnicze okresy: od lat 30. XVI wieku do końca epoki książęcej, od 2. połowy XVII do końca XVIII wieku (doba brandenbursko-pruska) oraz od początku XIX po połowę XX wieku. W dalszej części artykułu poruszono problem bardzo słabego wykorzystania pomorskich i nowomarchijskich ksiąg metrykalnych w pracach badawczych zarówno historyków niemieckich, jak i polskich. W jednakowym stopniu dotyczy to okresu przedwojennego, jak i czasów powojennych. Trzeba również podkreślić, że na ostateczny kształt przechowywanego dziś w Szczecinie zbioru ksiąg metrykalnych olbrzymi wpływ wywarła II wojna 
światowa. To ona doprowadziła do dużych strat oraz rozproszenia tego typu źródeł, które obecnie przechowywane są w archiwach niemieckich (Greifswald, Berlin) oraz polskich (Gorzów Wlkp., Koszalin, Szczecin). Następnie w pracy opisano pod względem archiwalnym szczeciński zbiór ewangelickich ksiąg metrykalnych, który liczy sobie 232 j. a., co daje łącznie 10,5 m. b. akt wytworzonych w latach 1581-1947. Jednak zasadniczą częścią niniejszego artykułu jest omówienie zawartości treściowej wszystkich serii ksiąg wchodzących w skład szczecińskiego zbioru (urodzenia, śluby, zgony). Przede wszystkim scharakteryzowano zapisy zawarte w najstarszych księgach z początku XVI i XVII stulecia, a następnie szczegółowo opisano przykładowe księgi z XVIII wieku i to zarówno te z okresu przed tabelarycznego (pierwsza połowa stulecia), jak i z czasów, gdy wszystkie dane umieszczane były przez pastorów w specjalnie opracowanych tabelach (druga połowa stulecia). Na koniec przeanalizowano zapisy umieszczone $\mathrm{w}$ tabelach znajdujących się we wszystkich seriach ksiąg z XIX i 1. połowy XX wieku. Efektem tych prac było wskazanie podobieństw i różnic w zapisach zawartych w różnych seriach ksiąg metrykalnych na przestrzeni ponad 350 lat. Wskazano także na różnice między tabelami wypełnianymi w parafiach pomorskich a nowomarchijskich. Na końcu, podkreślając wartość poznawczą pomorskich i nowomarchijskich ksiąg metrykalnych, sformułowano wnioski dla osób, które ewentualnie chciałyby się zająć badaniami z zakresu demografii historycznej na podstawie tych właśnie źródeł. 